\title{
Effects of interaction between cowpea variety and the application of plant powders on Callosobruchus maculatus (Fabricius) (Coleoptera: Chrysomelidae) infestation of stored cowpea seeds
}

\author{
Owolabi Moshood Azeez ${ }^{1}$, Adebola Adedoyin Osipitan'2, Isaac Oludayo Daniel ${ }^{3}$ \\ and Olufemi Olutoyin Richard Pitan ${ }^{2 *}$
}

\begin{abstract}
Submitted: 13 March 2019 | Accepted: 12 November 2019

An integrated pest management scheme involving seed resistance and the application of powder of Cymbopogon citratus, Alstonia boonei, Hyptis suaveolens, Azadirachta indica, Loranthus braunii and Lycopersicum esculentum as protectant against the seed bettle, Callosobruchus maculatus (Fabricius), was evaluated in the laboratory at ambient temperature $\left(29 \pm 3^{\circ} \mathrm{C}\right)$ and relative humidity $(65 \pm 5 \%)$. Six resistant cowpea accessions selected from previous studies were treated with the six plant powders at $1.25 \% \mathrm{w} / \mathrm{w}$ in a $6 \times 7$ factorial arrangement fitted into a completely randomized design with five replicates. Seed treatment with any of the six plant powders on six accessions resulted in significantly higher adult mortality, lower oviposition rate, adult emergence inhibition, lower seed damage and higher seed germination over the control. Protection ability of the plant powders was influenced by the cowpea accessions used.
\end{abstract}

Keywords: cowpea resistance, accessions, botanicals, integrated Callosobruchus maculatus management

\section{INTRODUCTION}

Cowpea occupies a unique place as the most widely cultivated and utilized grain legume in Nigeria (Eaglesham et al 1992). It is cultivated for its seed (shelled green or dried), pods or leaves, which are consumed in fresh form as green vegetables, while snacks and main meal dishes are prepared from the dried grains. Cowpea is one of the cheapest proteins in the diet of Nigerians providing over $57 \%$ protein from leguminous sources (Padulosi \& Ng 1997). All the plant parts used for

Department of Crop and Soil Science, University of Port Harcourt, Choba, Port Harcourt, Nigeria ${ }^{2}$ Department of Crop Protection, Federal University of Agriculture, Abeokuta, Nigeria

${ }^{3}$ Department of Plant Breeding and Seed Technology, Federal University of Agriculture, Abeokuta, Nigeria

*Corresponding Author. Address: Department of Crop Protection, Federal University of Agriculture, Abeokuta, Nigeria; Email: femipitan@yahoo.com DOI: $10.32945 /$ atr4213.2020 
food are nutritious, making it extremely valuable where many people cannot afford protein foods such as meat and fish.

Insect pests are reported to be the single most important constraint to cowpea production (Singh et al 1990, Pitan \& Odebiyi 2001, Pitan et al 2007). Callosobruchus maculatus $F$. which attacks stored cowpea seeds, is also known to infest the crops in the field prior to harvest (Hagstrum 1985, Potnaik et al 1986). The practice by Nigerian farmers in which the pods are left in heaps after harvest or the whole plant is harvested and the pods are removed later, facilitate attack by $C$. maculatus (van Huis 1991). During storage which is the longest post-harvest phase of the crop, seed damage could be over $90 \%$ due to the insect pests (Caswell 1982). Although the degree of damage in the field is usually as low as $2 \%$, it provides a dangerous nucleus for infestation during the storage period that may be as long as 9 months in many parts of Nigeria (Caswell 1970, 1982). The severe damage caused by this pest lowers the quality and quantity of the cowpea available for consumption. Seed viability is adversely affected with three or more emergence holes per seed (Singh \& van Emden 1979). In addition to the physical damage caused by $C$. maculatus the fatty acid content of infested seed is increased causing a slight denaturation of proteins. There is also a loss of an important vitamin, thiamine, from infested seeds (Southgate 1978). Consequently, the quality of stored cowpea grains can be lost through changes in their texture, taste, appearance, reduced nutritional values and the over-all marketability. Heat, moisture and waste products produced by the beetle also result in further deterioration and growth of moulds (Shazia et al 2006).

Although chemical control of the beetle is effective, the consequences of frequent insecticide use, coupled with inadequate supply and high cost of insecticides, create a need for research on non-chemical methods such as the use of botanicals. Insecticidal natural products from locally available plants are gaining ground recently as alternatives to synthetic pesticides in storage. Reports abound in literature on the efficacy of Cymbopogon citratus (DC. ex Nees) Stapf., Alstonia boonei De Wild, Hyptis suaveolens (L) Poit, Azadirachta indica A. Juss., Loranthus braunii Engl.and Lycopersicon esculentum Mill. against $C$. maculatus (Singh \& van Emden 1979, Ivbijiaro 1983, Fatope et al 1995, Makanjuola 1989, Ogunwolu \& Idowu 1994, Ogunwolu \& Odunlami 1996, Azeez 2012). On the other hand, use of resistant varieties, which is a promising solution to the menace of storage pests, including $C$. maculatus (Serratos et al 1987), is one of the most economical and environmentally safe methods of pest control, and is the bedrock of any integrated pest management (IPM) programme.

Six resistant cowpea lines (IT06K-141, IT04K-334-2, IT04K-343-1, IT99K-494-6, IT99K-529-2 \& IT99K-216-48-1) were found to give some level of resistance against the cowpea seed beetles (Azeez 2012). However, resistance in most pest problems does not last for a long time because of the development of virulent biotypes (Adane 1995) that are tolerant to the resistant mechanism(s) of the host plant. A notable example in this respect is TVu 2027, a resistant cowpea variety, which had become ineffective against certain biotypes of $C$. maculatus (Dick \& Credland 1986). In view of the highlighted problems, there is the need to develop a long-term integration strategy for the protection of cowpea seeds in store involving the incorporation of the resistant varieties and the tested botanicals. The most attractive feature of using varietal resistance is that the grower needs no extra skill or cash investment, and that of botanicals is that local farmers are traditionally 
Effects of interaction between cowpea variety and the application of plant powders

familiar with them. Each of the six cowpea varieties and the six plant powders selected for this study had been reported previously to have significant adverse effect on C. maculatus (Azeez 2012). Therefore, the objective of this study was to evaluate the potential of the interaction between cowpea varietal resistance and the application of six plant powders for the management of $C$. maculatus on stored cowpea seeds.

\section{MATERIALS AND METHODS}

\section{Rearing of Experimental Insects}

An initial 200 unsexed adult $C$. maculatus was obtained from the culture maintained on 'Ife Brown' cowpea variety in the Department of Crop Protection, Federal University of Agriculture, Abeokuta, Nigeria. Fifty adults were introduced into each $500 \mathrm{~mL}$ Kilner jar containing $200 \mathrm{~g}$ of clean disinfested Ife Brown cowpea seeds, making four jars. The Kilner jars were covered with muslin cloth held in place by a screw cap in order to allow aeration and to prevent insect escape. The set-up was kept under ambient temperature $\left(27-30^{\circ} \mathrm{C}\right)$ and relative humidity $(70-85 \%)$. The insects were allowed to mate for seven days and lay eggs in each of the jars after which they were removed. The devoured seeds were replaced continuously with freshly disinfested seeds. Only the new adult beetles emerging from the culture were used for the experiment.

\section{Sources of Seeds}

Six resistant cowpea lines used for this study: IT06K-141, IT04K-334-2, IT04K343-1, IT99K-494-6, IT99K-529-2 and IT99K-216-48-1, were obtained from the Genetic Resource Unit, International Institute for Tropical Agriculture (IITA), Ibadan, Nigeria. The cowpea seeds were disinfested using cold shock treatment at 0 to $4^{\circ} \mathrm{C}$ for seven days.

\section{Plant Materials}

The six insecticidal plant species used were sourced from different ecological zones in South West, Nigeria, and were identified at the Department of Forestry and Wildlife, College of Environmental Resources Management, Federal University of Agriculture, Abeokuta, Nigeria. Plant leaves were washed in clean water and were later air-dried and ground into fine powder using an electric grinder. The powder was further sieved in $100 \mu \mathrm{m}$ apperture sieve.

\section{Efficacy Evaluation of Plant Powders and Resistance Combination}

Each of the powdered six botanicals was mixed with $20 \mathrm{~g}$ of disinfested cowpea seeds of each of the six varieties in a Kilner jar at $1.25 \% \mathrm{w} /$ w concentration and thoroughly mixed. Ten pairs ( $1: 1$ male: female) of teneral adult ( $<24 \mathrm{~h}$ old) $C$. maculatus were introduced and confined into each Kilner jar over 7 days for mating and oviposition. The seeds in the control jars contained only disinfested cowpea seeds without any plant powder. The Kilner jars were arranged on the laboratory work bench in a $6 \times 7$ factorial arrangement fitted into a completely randomized 
design with five replicates under fluctuating laboratory conditions $\left(27-30^{\circ} \mathrm{C} \& 70\right.$ $85 \% \mathrm{RH})$. Mortality was taken daily until day 7 when all the bruchids were removed and the number of eggs laid was recorded. At 31, 62 and 93 days after infestation, number of dead and live bruchids, representing $F_{1}, F_{2}$, and $F_{3}$ generations respectively, were collected from the jars. After 12 weeks, the contents of each Kilner jar were sieved to remove the dust frass and any insect present in the jars. Thereafter, the number of the bruchids found in the jars was recorded.

Germination tests were carried out in sterile Petri dishes $(9 \mathrm{~cm}$ diameter) lined with Whatman No. 1 filter paper moistened daily with distilled, de-ionized water. One hundred seeds randomly selected from each treatment were germinated in four replicates of 25 seeds per replicate. The number of germinated seeds were counted and recorded after three days.

\section{Statistical Analysis}

All data collected were subjected to Analysis of variance (ANOVA) using SAS (2002) method. Significant means were separated using Student-Newman-Keuls test at $5 \%$ probability.

\section{RESULTS AND DISCUSSION}

Although there were significant variations among the six varieties in terms of $C$. maculatus mortality at seven days post-treatment, the parameter was jointly influenced by the type of plant powder and cowpea variety used (Table 1). While $100 \%$ beetle mortality was recorded when IT04K-343-1, IT06K-141,IT99K-529-2 and IT99K-216-48-1 seeds were mixed with $C$. citratus, $A$. boonei, $H$. suaveolens and $A$. indica, respectively, this value was not significantly different from the mortality recorded in the other treated seeds, and was higher than the control. The highest beetle mortality value was recorded on 04K-342-1 treated with A. Indica A significant reduction in number of eggs was recorded on accessions IT04K-334-2 and IT04K-141 treated with C. citratus, L. braunii, H. suaveolens, A. indica, A. boonei and $L$. esculentum powder (Table 2).

Adult beetle emergence (Table 3 ) and seed damage (Table 4) were significantly influenced by cowpea variety and plant powder, and were lower in treated grains than the control, while seed germination was higher in treated seeds than the control (Table 5). Seed treatment with any of the plant powders gave total inhibition of beetle emergence and also reduced seed damage significantly, compared to the control (Table 4).

Many authors have reported $C$. citratus, $A$. boonei, $H$. suaveolens, $A$. indica, $L$. braunii and $L$. esculentum as good grain protectants against $C$. maculatus (Singh \& van Emden 1979, Ivbijiaro 1983, Fatope et al 1995, Makanjuola 1989, Ogunwolu \& Idowu 1994, Ogunwolu \& Odunlami 1996, Azeez 2012). Nevertheless, total reliance on the use of these plants, as well as other botanicals, for the control of $C$. maculatus may result in the development of resistant strains through selection. However, this study showed that integrating any of the plant powders with seed resistance significantly enhanced cowpea seed protection against the seed beetles. The study also showed that the ability of a botanical to provide protection depends on the cowpea variety used. 
Effects of interaction between cowpea variety and the application of plant powders

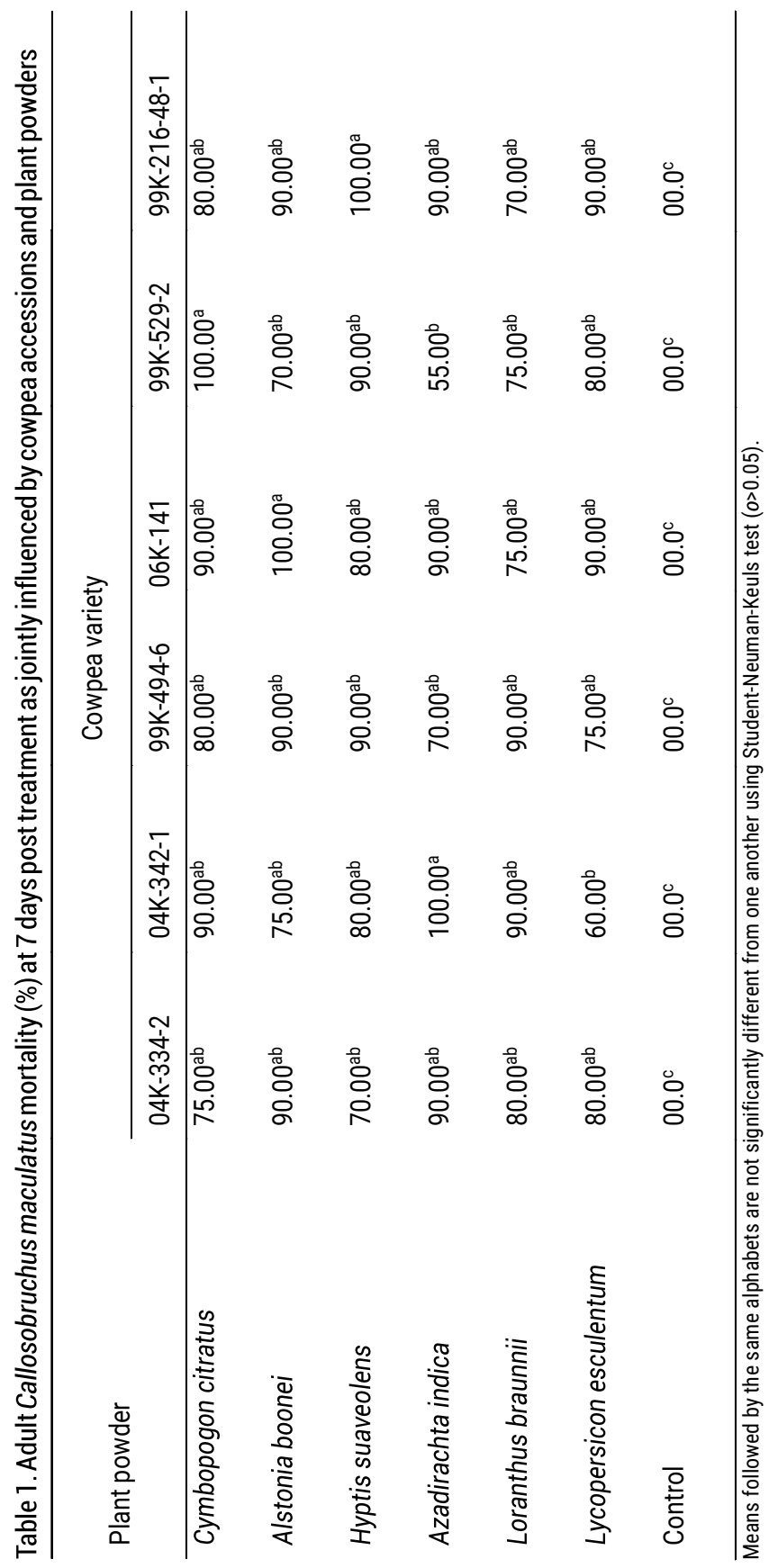


Azeez et al

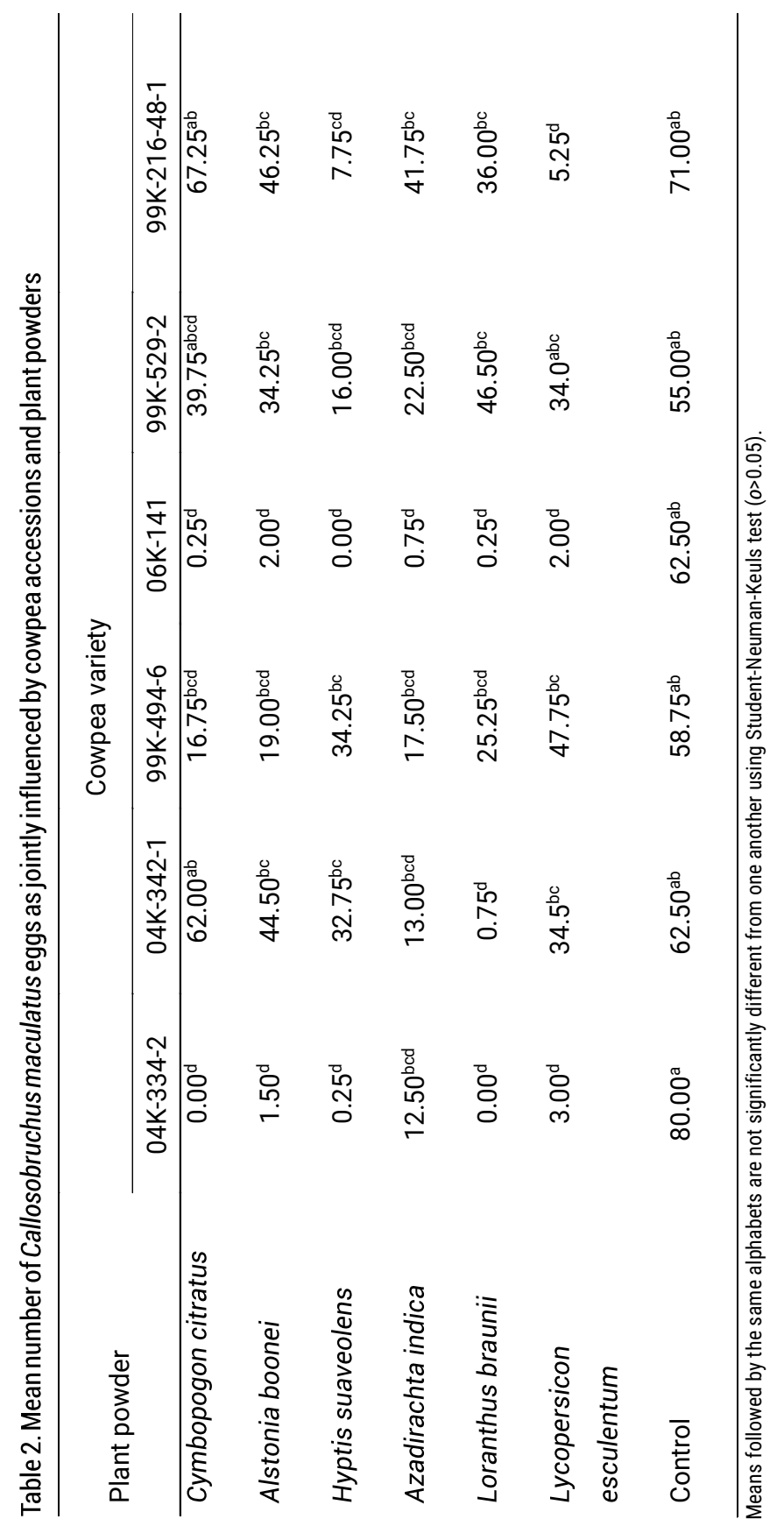


Effects of interaction between cowpea variety and the application of plant powders

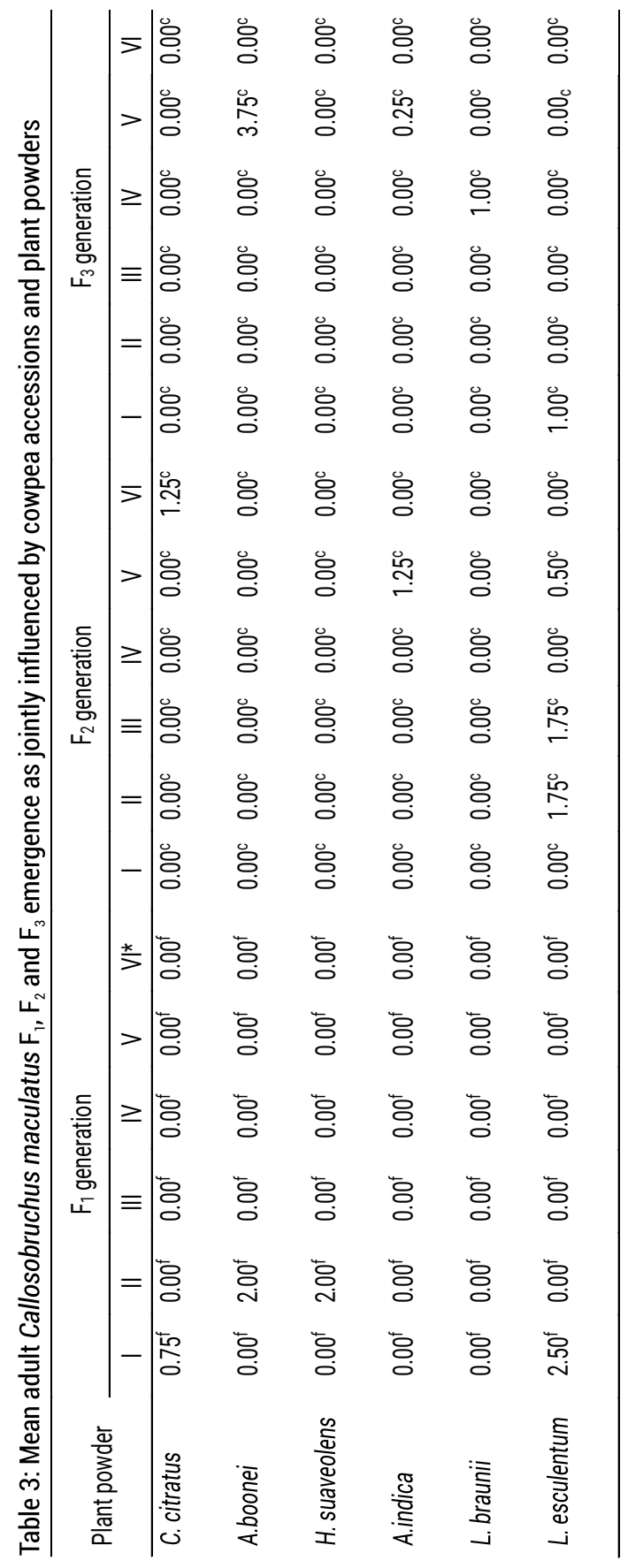


Azeez et al

Table 4. Seed damage (\%) induced by Callosobruchus maculatus as jointly influenced by cowpea accession and plant powders

\begin{tabular}{|c|c|c|c|c|c|c|}
\hline \multirow{2}{*}{ Plant powder } & \multicolumn{5}{|c|}{ Cowpea variety } & \multirow[b]{2}{*}{$99 \mathrm{~K}-216-48-$} \\
\hline & $04 K-334-2$ & 04K-343-1 & $99 K-494-6$ & $06 \mathrm{~K}-141$ & $99 K-529-2$ & \\
\hline Cymbopogon citratus & $2.13^{c}$ & $0.00^{c}$ & $0.00^{c}$ & $0.00^{c}$ & $0.00^{c}$ & $2.75^{c}$ \\
\hline Alstonia boonei & $0.00^{c}$ & $6.87^{c}$ & $1.87^{c}$ & $0.00^{c}$ & $0.00^{c}$ & $2.12^{c}$ \\
\hline Hyptis suaveolens & $0.00^{c}$ & $3.13^{c}$ & $0.00^{c}$ & $0.00^{c}$ & $4.37^{c}$ & $0.00^{c}$ \\
\hline Azadirachta indica & $2.63^{c}$ & $0.00^{c}$ & $0.00^{c}$ & $0.00^{c}$ & $1.00^{c}$ & $0.00^{c}$ \\
\hline Loranthus braunnii & $0.00^{c}$ & $0.00^{c}$ & $1.25^{c}$ & $3.75^{c}$ & $0.00^{c}$ & $0.00^{c}$ \\
\hline Lycopersicon esculentum & $4.25^{c}$ & $4.50^{c}$ & $0.00^{c}$ & $0.00^{c}$ & $0.00^{c}$ & $0.00^{c}$ \\
\hline Control & $28.00^{\mathrm{a}}$ & $20.50^{\mathrm{ab}}$ & $23.25^{\mathrm{ab}}$ & $17.50^{b}$ & $16.25^{b}$ & $15.00^{b}$ \\
\hline
\end{tabular}

Table 5. Percent germinated seeds as influenced jointly by cowpea accessions and plant powders

\begin{tabular}{|c|c|c|c|c|c|c|}
\hline \multirow{2}{*}{ Plant powder } & \multicolumn{6}{|c|}{ Cowpea variety } \\
\hline & 04K-334-2 & $04 K-343-1$ & $99 K-494-6$ & 06K-141 & $99 K-529-2$ & $99 K-216-48-1$ \\
\hline Cymbopogon citratus & $72.50^{\mathrm{a}}$ & $70.00^{a}$ & $72.50^{\mathrm{a}}$ & $70.00^{\mathrm{a}}$ & $67.50^{\mathrm{a}}$ & $52.50^{\mathrm{a}}$ \\
\hline Alstonia boonei & $70.00^{a}$ & $70.00^{a}$ & $52.50^{\mathrm{a}}$ & $65.00^{\mathrm{a}}$ & $70.00^{a}$ & $70.00^{a}$ \\
\hline Hyptis suaveolens & $70.00^{a}$ & $57.50^{\mathrm{a}}$ & $70.00^{\mathrm{a}}$ & $72.50^{\mathrm{a}}$ & $57.50^{\mathrm{a}}$ & $67.50^{\mathrm{a}}$ \\
\hline Azadirachta indica & $52.52^{\mathrm{a}}$ & $70.00^{a}$ & $70.00^{\mathrm{a}}$ & $65.00^{\mathrm{a}}$ & $70.00^{\mathrm{a}}$ & $70.00^{a}$ \\
\hline Loranthus braunii & $75.00^{a}$ & $85.00^{a}$ & $70.00^{a}$ & $70.00^{\mathrm{a}}$ & $72.50^{\mathrm{a}}$ & $55.00^{a}$ \\
\hline Lycopersicon & $70.00^{a}$ & $52.50^{a}$ & $70.00^{\mathrm{a}}$ & $67.50^{\mathrm{a}}$ & $70.00^{\mathrm{a}}$ & $70.00^{\mathrm{a}}$ \\
\hline esculentum & & & & & & \\
\hline Control & $2.50^{\mathrm{b}}$ & $10.00^{b}$ & $12.50^{b}$ & $8.75^{b}$ & $11.25^{b}$ & $5.00^{b}$ \\
\hline
\end{tabular}


Effects of interaction between cowpea variety and the application of plant powders

The higher adult $C$. maculatus mortality, fewer eggs laid, and total inhibition of adult emergence recorded relative to the control could be a result of synergism between the bioactive principles in the plant powders and the antibiosis properties inherent in the resistant cowpea varieties. From literature, plant powders reduce insect movement and also cause death through occlusion of their spiracles thereby preventing respiration via trachea (Shukla et al 2008). They may also protect seeds by blocking the respiratory pore of eggs and being toxic to the immature stages and adults of $C$. maculatus (Adedire \& Lajide 2000). Similarly, the characteristics of the seeds could have improved the adhesion of powders in the seed surface resulting in the differences observed in the activity of each powder on different accessions used.

The high seed germinability observed in protected cowpea seeds was due to the lower seed damage recorded on treated seeds and the beneficial interaction of the powders with the seed cotyledons, indicating that the reduction in C. maculatus infestation was without any adverse effect on seed quality.

Although $A$. indica, and L. esculentum gave lower adult mortality on IT99K529-2 and IT04K-342-1, respectively, suggesting lower bioactivity, they eventually both made up for this shortcoming by inhibiting adult emergence totally, thus reducing seed damage to a level that is not statistically different from those of other botanicals. The mechanism of action is suggested to involve biochemical reactions or interactions. In addition, the integration interactions may likely cause a delay in the emergence of biotypes of the beetles that are capable of breaking down resistance in cowpea varieties or strains of $C$. maculatus that are resistant to the plant powders.

One of the advantages of using host plant resistance is its compatibility with other control methods, making it the bedrock of modern pest management, and if resistant cowpea varieties combined in a compatible manner with other control methods, effective and sustainable pest management would be achieved (Arnason et al 1992). The integration of the plant powders with varietal resistance therefore appears to have great potential for the management of $C$. maculatus in stored cowpea. Earlier studies have also demonstrated the enormous potentials inherent in integrating botanicals with varietal resistance to protect stored products against insect pests (Lale \& Mustapha 2000, Ajayi \& Lale 2001, Ashamo 2005).

\section{CONCLUSIONS}

In conclusion, the results show significant adverse combination effects of the plant powders and varieties resistance on $C$. maculatus. The data also indicated the possibility of ovicidal/larvicidal of the powders and antibiosis activity in the varieties with more eggs laid. Since the botanicals are readily available (Irvine 1961), and the resistant cowpea seeds are also available, the adoption of the integration of cowpea resistant varieties and the plant powders by resource-poor farmers in the tropics to prevent losses experienced in stores and fields would not be difficult.

Since the plants are consumed in one way or the other by humans, it is therefore recommended that any of the plant powders tested in this study can, for $C$. maculatus management, be incorporated, into cowpea seeds stored for human consumption and animal feeds. 


\section{ACKNOWLEDGMENT}

The authors are grateful to the International Institute for Tropical Agriculture (IITA), Ibadan, Nigeria, and the Institute for Agricultural Research and Training, Ibadan, Nigeria for providing the cowpea cultivar used at different times for this study.

\section{REFERENCES}

Adane K. 1995. Integrating biological control and host plant resistance (Cereals Working Group Reports) (pp27-28). Summary report and commendations of a CTA/IARL/IBE Seminar, Addis Ababa, Ethiopia, 9-14 October 1995

Adedire CO and Lajide L. 2000. Toxicity and oviposition deterrency of some plants extracts on cowpea Storage bruchid Callosobruchus maculatus Fabricius. Journal of Plant Disease and Protection 106(6):647-653

Ajayi FA and Lale NES 2001. Susceptibility of unprotected seeds of local bambara groundnut cultivars protected with insecticidal essential oils to infestation by Callosobruchus maculatus (F.) (Coleoptera: Bruchidae). Journal of Stored Products Research 37(1):47-62

Arnason JT, Gale J, Conich DE Beyssac B, Sen A, Miller SS, Philegene BJR, Lambert JDH, Fulcher RG, Serratos A \& Mihm J. 1992. Role of phenolics in resistance of maize grain to the stored grain insect, Prostephanus truncatus (Horn) and Sitophilus zeamais (Motsch). Journal of Stored Products Research 28(2):1191126

Ashamo MO. 2005. Integration of varietal resistance and nutmeg, Myristica fragrans (Houtt.) oil in protecting post-harvest infestation by Sitophilus oryzae (L.) in rice. Journal of Entomological Research 29(4):259-263

Azeez OM. 2012. Studies on host resistance integrated with botanicals for the control of cowpea seed bruchid, Callosobruchus maculatus (Fabricius) (Coleoptera:Bruchidae) (PhD dissertation). Federal University of Agriculture, Abeokuta

Caswell GH. 1970. The use of insecticides in Nigeria. Bulletin of Entomological Society of Nigeria 2:111-114

Caswell GH. 1982. Damage Stored Cowpea in the Northern part of Nigeria. Samaru Journal of Agricultural Research 1:111-191

Dick KM and Credland PF. 1986. Variations in the response of Callosobruchus maculatus (F.) to a resistant variety of cowpea. Journal of Stored Products Research 22(1):43-48

Eaglesham ARJ, Stowers MD, Sinclair MJ \& Ayanaba AG. 1992. Patterns of diversity of cowpea- miscellany rhizobia from three West-Africa locations. In Ghai BS (ed) Symbiotic Nitrogen Fixation (pp120-125). USG publisher and distribution, Ludhiana

Enobakhare DA and Law-Ogbomo KE. 2002a. Efficacy of leaf powder of Vernonia amygdalina and Ocimum gratissimum as grain protectants against Sitophilus zeamais (Motsch) (Coleoptera: Curculionidae) in three maize varieties. Journal of Agriculture, Forestry and Fisheries 3(1):22-27

Enobakhare DA and Law-Ogbomo KE. 2002b. Reduction of post-harvest loss caused by Sitophilus zeamais (Motsch) in three varieties of maize treated with plant products. Postharvest Science 1:1-6 
Effects of interaction between cowpea variety and the application of plant powders

Fatope MO, Nuhu AM, Mann A \& Takada Y. 1995. Cowpea C. maculatus bioassay; a simple prescreen for plants with grain protectant effects. International Journal of Pest Management 41(2):84-86

Hagstrum DW. 1985. Pre-harvest infestation of cowpeas by the cowpea $C$. maculatus (Coleoptera: Bruchidae) and population trends during storage in Florida. Journal of Economic Entomology 78:358-361

Irvine FR. 1961. Woody Plants of Ghana. Oxford University Press, Oxford

Ivbijaro MF and Agbaje M. 1986. Insecticidal activities of Piper guineense and Capsicum spp. On the cowpea bruchid Callosobruchus maculatus (F.). Insect Science and its Application 7(4):521-524

Lale NES and Mustapha A. 2001. Potential of combining neem (Azadirachta indica A. Juss) seed oil with varietal resistance for the management of the cowpea brucchid, Callosobruchus maculatus. Journal of Stored Products Research 36(3):215-222

Makanjuola WA. 1989. Evaluation of extracts of neem (Azadirachta indica A. Juss ) for the control of some stored product pests. Journal of Stored Products Research 25(4):231-237

Ogunwolu EO and Idowu OT. 1994. Potential of powdered Zanthoxylum zanthoxyloides (Rutaceae) root bark and Azadirachta indica (Meliaceae) seed for the control of cowpea seed bruchid, Callosobruchus maculatus (Bruchidae) in Nigeria. Journal of African Zoology 108:521-528

Ogunwolu EO and Odunlami AT. 1996. Suppression of seed bruchid Callosobruchus maculatus (F.) development and damage on cowpea (Vigna unguiculata (L.) Walp.) with Zanthoxylum zanthoxyloides Waterm. (Rutaceae) root bark powder when compared to neem seed powder and pirimiphosmethyl. Crop Protection 15:603-607

Padulosi S and $\mathrm{Ng} \mathrm{NQ}$. 1997. Origin, taxonomy and eco-geograghic survey of the wild relatives of cowpea (V. unguiculata (L.) Walp. In Singh BB, Mohan Raj DR, Dashiell KE \& Jackai LEN (eds) Advances in Cowpea Research (pp1-12). Copublication International Institute Tropical Agriculture (IITA) and Japan International Research Agricultural Science (JIRCAS), Sayce, Devon, United Kingdom

Pitan OOR and Odebiyi JA. 2001 Crop loss in cowpea due to the pod-sucking bugs, Riptortus dentipes, Mirperus jaculus, Anoplocnemis curvipes and Nezara viridula. Insect Science and Its Application 21:237-241

Pitan OOR, Odubiyi SII \& Olatunde GO. 2007. Yield response of cowpea, Vigna unguiculata L. (Walp.), to infestation of Aspavia armigera F. (Hemiptera: Pentatomidae). Journal of Applied Entomology 131(9-10):704-708

Potnaik NC, Panda N \& Dash AN. 1986. Effect of sowing date and cultivar on field infestation of pulse beetle of pigeon pea. International Pigeon Pea Newsletter 5:44-46

Serratos A, Arnason J, Nozzolillo C, Lambert J, Philogene B, Fulcher G, Daindson K, Peacoak J, Atkinson J \& Morand P. 1987. Factors contributing resistance to exotic maize populations to maize weevil, Sitophilus zeamais. Journal of Chemical Ecology 13:751-761

Shazia OWM, Minza M, Rhodes M, Robert NM, Bukheti K, Maulid M, Herman FL, Christine GI, Dastun GM \& Loth SM. 2006. Control of cowpea C. maculatus (Callosobruchus maculatus F.) in stored cowpea (Vigna unguiculata L.) grains using botanicals. Asian Journal of Plant Sciences 5(1):91-97 
Singh SR and Van Emden HF. 1979. Insect pests of grain legumes. Annual Review of Entomology 24:255-278

Singh SR, Jackai LEN, Dos Santos JHR \& Adalla CB. 1990. Insect pests of cowpea . In Singh SR (ed) Insect Pests of Tropical Food Legumes (pp43-89). John Wiley \& Sons, Chichester

Southgate BJ. 1978. The importance of the Bruchidae as pests of grain legumes: their distribution and control. In Singh SR, van Emden HF \& Taylor TA (eds) Pests of Grain Legumes: Ecology and Control (pp219-229). Academic Press, London, UK

Van Huis A.1991. Biological methods of bruchid control in the tropics: A review. Insect Science and its Application 12(1/2/3):87-102 